\title{
Olfactory Communication: Olfaction Process and Communication Relation
}

\author{
Research Asist. Sanem Bengü Uygunkan \\ Anadolu University
}

\begin{abstract}
Smell is a characteristic of every living or non-living being has in nature. Sensitivity to sense of smell and the areas of influence can vary depending on the species of living beings and the physical structures of brain and nose. This variation causes various differences in the same species. Besides the intersexual differences among humanbeings, sense of smell and emitting smell according to the periods of women bring along the changes in emotions and attitudes. Sense of smell is a sense that every living being has voluntarily or involuntarily and it is related to interpersonal communication which is even called inter communication system and the communication a person has with himself. In addition to this, smell is used as a marketing tool and marketing strategy in the marketing sector in which the importance of smell is realized. There are searches and usages that shape the communication process and make it as attractive as the audiovisual aid at least. By explaining the process of sense of smell of living beings and humanbeings, this study aims at revealing the relation between this process and the communication process.
\end{abstract}

\section{How Do We Smell?}

Smell is of great importance for the living of many species because it is the first thing between environment and us. The difference between people and the other living beings in terms of smell is that it plays a crucial role for the other species' survival. Many animals use the sense of smell in order to survive. Determining his place, marking his location, finding certain places, other animals and food resource depend on his olfaction. At the same time, smell is highly important in breeding because it triggers species' mating behaviours. (Goldstein 2007, s. 328)

All the substances making up the nature give off smell by way of molecules. Animals use their olfaction in order to find others, communicate with each other and hunt. Plants use their olfaction in order to pollinate and pull the insect towards themselves or ward them off. People's smell differs in the smell secreted from human bodies, psychological state and physiological property. As the speed of hormone secretion may change according to the human state of mind (being happy and sad or hate etc.), secreted hormones may differ. Everyone has a typical smell and this can be explained by genetics. But the first characteristic that differs people from other living beings in terms of sense of smell is that people do not have high olfaction threshold and so they cannot categorize it deliberately in a way to distinguish it from another person even if they get the smell (n.d. 2017).

The gene $O R$ is a gene family that provides people to smell. $5-7 \%$ of human brain belongs to smelling parts. 900 OR genes providing olfaction are detected. In time, with the evolving of mammals some these genes have lost their function (According to Antropogeni Academical Search and Training Center the percentage is 60\%.). Due to the lack of these genes, cells cannot produce necessary smell receptors. People's olfaction 
repertory gets narrow. In comparison with animals, human sense of smell has rather reduced. (n.d. 2017).(2)

People can mostly sense some smell with low intensity. However, mice for example are 8-50 times more sensitive than people, depending on the smell and dogs are 300-10000 times more sensitive. Even though people cannot sense smell as much as animals, their personal smell receptors are as sensitive as animals' (Goldstein, 2007, s. 329).

How can one smell? Every living being and things' molecules get into the air and with this air smell comes to nose. There are smell epitheliums that provide living beings to smell, change in size according to species, as they widen sense of smell increase, happen to be in nasal cavity and cover $4 \%$ of this cavity. There are mucus epithelium in nose. Odorizers and receptor molecules in the nose react and these reacted molecules affect permeability of the cell membrane. As a result of this change impulses ocur. Impulses move to olfactory center in brain. By analyzing these impulses in brain, living beings smell. In smelling epitheliums of a young person there are aproximately 25 million receptor cells and the life span of these cells is 30 days. At the end of 30 days they renew. People can distinguish almost ten thousand different smells by means of 6-8 smell receptors in these cells. (n.d. 2017).

The olfaction intensity begins to diminish after a while exposed to smell. It is not the smell that disappears. Although there are still smell molecules, people cannot sense it any longer. Babies and cildren do not get disturbed by the smells that adults do. Trygg Engen (narrater Ozan) narrates that very little of smell choice comes by birth and the rest is learned in social life. Engen states that smell appeals to emotion and mood. Olfaction is a state that penetrates into self and environment, provides people to react and it cannot be denied in any situation and also this is sticked into their minds. (Ozan, 2014, s. 280-283).

\section{What are the Results of Olfaction?}

The most important factors that affect olfaction are age and gender. Olfaction in people at the age of 60 and above begin to diminish. Studies show that women have a sharper olfaction than men. (n.d. 2017).

Polat indicates that human olfaction affects $75 \%$ of daily senses and plays an important role for memory. As olfaction is located in brain, it is closely related to memory, state of mind, stress and concentration. Academician and researchers with the help of the results they get reveal that smell creates a link between state of mind, memory, senses, mate selection, immune system and hormones. Another important function of olfaction is waking memories. Diminish in olfaction causes to dysmnesia (poor memory) in some patients. At the time of smelling, smelling cells in the part examining this smell manage the center of brain responsible for sensory learning. This center has also a function on relations and memories and experiences are coded by way of this center. In other words, olfactory cells and center of sensory memory are closely associated with each other. While scent exhilarates and give senses like enthusiasm, happiness and feeling of self reliance to a person, some smells have soothing or relaxing effects. People can prefer not to see someone they do not like his smell and they may not want to go somewhere they do not like its smell (Polat 2017).

Olfaction is directly related to llimbic system and another important part of this system is "amygdala". Amygdala is the part that organize behavioral, neurotic, immunal and hormonal reactions to environmental warnings. At the same time it is this organ where formation of long term memory is provided. Its another function is to make decisions according to the threat levels of incoming signals by comparing the signals from environment and memories in mind. In short, the importance of "amygdala" in terms of 
olfaction can be summarized as; amygdala is a kind of sensory reaction production center. Its importance in terms of olfaction is that olfaction has a exclusively direct access to this part without passing through a cognitive filter (Ozan, 2014, s,33).

\section{Why are People Unable to Smell and what are the Results?}

Inability to perceive smell is called "anosmia". Anosmia can be temporary or permanent depending on its cause. While it can be temporary in cases of nasal congestion, there can be a permanent situation if it happens to be something related to brain tumour. Zinc deficiency also hinders smelling. Hyposmia is a decreasing ability to smell and Hyperosmia is an increase in smelling ability compared to other people. All these 3 situations can be totally or partly dependent on a certain situation. Phantosmia is the olfactory hallucinations even if there not smell. Parosmia is an olfactory disfunction of the present smell. And kakosmia is getting smells as malodour. Scientifically, not being able to smell is analysed in two ways. One is "type of communication" the reasons that hinder olfactory particles to reach olfactory cells. And the other way, "sensorineural type" is olfactory disorders caused by olfactory nerves and tracts. (n.d. 2015)

Inability to perceive smell may not seem as posing a direct threat for health but someone with olfactory loss cannot get the smell and taste of meals. The patient may not want to eat and his loss of apettite will cause weight loss, malnutrition an deven depression. As they are not able to smell rotten food, they may get food poisining. On the other hand, they cannot get any poisonous gas and they may get exposed to it for a long time and poisoned (n.d. 2015). Olfaction and sense of taste collaborates together. When someone chew any food, his nasal cavity also moves and the pervading smell molecules of food perceived. According to Finger (prof. Tom Finger- Colorado, Denver Medical Faculty) when some food is eaten by congesting nose and does not smell, one cannot get the taste of it and especially the complicated tastes cannot be distinguished. (n.d. 2017). (2)

Searches and discussions conducted on people with anosmia show that they cannot get the taste of what they eat. Because they cannot make a connection between taste and smell of the food. A woman with anosmia after she regained her sense of smell even a little has told that "If I had to make a selection between olfaction and taste, I would always choose taste. But now I realize I have missed much. I can get the smell of people, my home, my skin and everything."(Goldstein, 2007, s. 329).

\section{What is Pheromone and its Effects on Communication?}

Pheromone is a word derived from Greek and it means "hormone agents". Pheromone is a chemical arranging social relations in the same species (n. d. 2017).(3). Pheromone is a general name given to some specifical chemicals of a species secreted in order to sense the individuals of the same species (n.d. 2017.)It was found in silkworms in 1956 for the first time and many different types of pheromone has been found as the results of conducted studies. It has been found out that insects, sipiders, frogs, reptiles and mammals secrete pheromone. But some species like birds do not have pheromone (n.d. 2017).(3). Aggregation pheremones, alarm pheromones, signal pheromones, trail pheromones, information pheromones, sex pheromones, epideictic pheromones, releaser pheromones, primer pheromones, territorial pheromones, calming pheromones and necromones are some types of pheromone. Pheromones are perceived directly by olfaction. It is perceived by Jacobson's Organ in the nose (n.d. 2017). (2)

Human pheromones are secreted from apocrine glands in armpits, sweat glands and and around sexual organs. Secretion of these chemicals increases especially in breeding periods. Body odour which has an important role for human culture includes essential pheromones for breeding. What is decreased in human with evolution is not secretion of hormones but their perception. Even if these pheromones are still secreted, our nasal 
sensitivity is decreased. Vomeronasal organ in nose is shrunk and all the receptors are disabled.

Three different types of pheromone have been detected that are secreted from human armpits until now. Females secreting Androstenone are more sympathetic and amiable. Androstenone secretion is something that changes skin electrical conductivity in both male and females. And this affects moisture equilibrium of the skin. Sympathetic nervous system of people exposed to this pheromone gets affected. So this situation make them sweat and get excited. Androstadien pheromone is the one triggering females' senses. The smell of this pheromone increases females' tolerance to pain and even it has changed their perception of pain. Females exposed to this pheromone become more tolerable and sensual towards male negative approach. This situation seems as a way to solve the problems in human population. Pheromones affect especially emotional approach that two opposite sex feel towards each other (n.d. 2017).(2).

Studies on human pheromones show that there is a connection between sexual attraction and love with smell. Smell is something crucial for being happy and breeding. Individuals being side by side and getting the smell of each other feel it intensely. Touching and being in the same environment increase pheromones and smell. In this case we can say that communication intensity increases. "Out of sight, out of mind." is an idiom used in Turkish. However, what is meant here may be that smell has something to do with dependence. When someone is away from the ones he loves and do not get their smell, pheromones communication will diminish and this will lead to distance. And perhaps what leads to distance is the disappearance of olfaction in brain. But there are some smells which brain identifies with each person and thing. As this smell is sensed from time to time, brain's recall mechanism activates.

\section{Olfaction and Communication}

Smell is an important way of communication. It provides advantage even when there is no light. Smelling is a significant way of communication and it makes huntee recognize the hunter, and hunter to recognize huntee, couples and relatives. Even deep in oceans where there is no light, decomposed chemicals can be detected by way of olfaction. Every species has developed different olfaction abilities according to their natural habitat. While olfaction is of primary importance for some species, it can be of secondary and tertiary importance for some other species. (n.d. 2017). (2)

Communication process occurs by communication channels. These channels are five senses which are sight, smell, hearing, taste and touch. The difference about sense of smell from other senses is that smell perception and emotion is in the same system called limbic system. Limbic system is not only the part that smell is processed but also it is the system providing the process of significant emotions such as liking, anger, pleasure, love, compassion, aggression and many other senses. This system works both in itself and other parts of brain and creates sensorium. Limbic system is also the "pleasure center of the brain" and it is an important part for sexuality. There is "memory" which directs our emotions, thoughts and attitudes for all our lives in limbic system. Other channels, senses in other words used in communication are connected to limbic system but first of all they are filtered in "thalamus" another part of the system and they proceed in brain. Olfaction's carrying nerve cells are directly connected to limbic system. In other words, olfaction is privileged and strong as it arouse a feeling without being filtered (Ozan, 2014, s, 29-30). The characteristic of this situation is that it causes direct reaction, accelerating communication proces, evoking associations from the past in the frame of reference at the time of olfaction. And sometimes it causes to keep out the logic, real and pure reactions. 
Smell has an important role in the process of human modernisation because it has a connection with memory correlatively with "learning". Studies show that recalling the smell of a boring and compelling environment leads to failure but smells recalling good memories create quiescence and a peaceful environment. Olfaction is a sense that provides "association". Smell is one of the factors that causes people's far approaches from each other at different ages and cultures (Ozan, 2014,s, 33-34).

In Professor doctor Gün Şemin and his colleagues' s study published in the journal "Psychological Science", they tried to explain how chemo signals affect communication. Male subjects are made to watch a 25 minute-long video triggering fear and disgust and then sweat samples are gathered from the subjects. Intermingling of the sweat is hindered as far as possible. And the subjects are asked for staying away from smoking, drinking alcohol and smelly foods for 2 days. Besides the subjects are given special detergent and personal care products. later on, women are given the sweat samples and their expressions and eye movements are watched. The women wear a face of fear towards "fear sweat" and a face of disgust towards "disgust sweat" (Semin, 2017).

Olfactory signals are not only the warning signals to the dangers in the environment but also by supplying sensual acquisition it provides necessary acts to survive. According to psychologist Professor Doctor Gün Semin and his colleagues' study, chemo signals affect communication. According to the hypothesis of their study, chemicals diffused from the body (e.g. sweat) can function as a transceiverand create a sensual expression. In other words, if the chemicals about fear is smelt, fear signals are given and if chemo signals about disgust are smelt, sensory refusal signals are given. This study indicates that communication is not only with language and visuality but also smell plays an important role in communication (Sezgin, Oğuz,2012).

Smelling something with lemon causes a perception of being healthy. Smelling lavender and eucalyptus causes hypervigilance and smelling rose oil reduces blood pressure. It has been found out that smelling chocolate reduces the theta waves in brain, provides emotional relief and causes distraction. Such findings contribute to aromatheraphy and aromatherapists. Because human scent glands band together in the skin more densely than all the other mammal animals. The rest subject at issue to be discovered is that how extensive and various olfactory messages use smell for communication. Some important olfactory messages that smell gives in communication are as below;

Attraction message: When people put on perfume, cologne, after-shave, powder and stuff like that, they become more attractive for themselves and the others. Fragrance make us feel better. It is thought that only women wear perfume and fragrance as primary consumers. Men used to use only after-shave and cologne. But recently body splash has been a line of work with 180 million-dollars.

Taste message: Without sense of smell the ability of tasting is affected negatively. For example, it is hard to distinguish between raw potato and apple without sense of smell. Vendors take the advantage of smell in order to arouse appettite of passers-by while selling snacks such as hot dogs.

Memory message: Smell is an important element for a good memory. A smell received several months and years ago when received again the same situation is remembered again.

Identity message: Smell is often used to create an image or identify products. Advertisers and producers spend million dollars to produce fragrance for cleaning products and tooth paste every year. Fragrance does not only show detergency of products but also it helps to create an image for a product. This situation is a proof that 
we can identify things with the help of smell at the same time. For instance, children have identified their brothers' and sister' t-shirts according to their smell in a study (Devito, 2008, s. 172).

Taste of smell is relative. It is this truth behind the statement "we are not a good match for each other" (we do not have chemistry with each other). If someone's smell does not trigger real and good memories in the memory module of brain and if this stimulates to the part arousing feeling of avoidance and repulsiveness, we may keep him at a distance. Someone's pleasant appearance does not always mean he will smell good. (Ozan, 2016, s. 95-96). There is not good and bad concept in the world of perfume. It is important to use it reasonably and know where to use the decent fragrance instead (Ozan, 2015, s. 574). Even though there are many complicated types of smell, we can primarily classify it in two ways as attractive and unattractive. Nietzsche claims that smell has a power to reveal the truths in subconscience and realize lie and intuitive sense (Landback, 2007).

Smell has some characteristics which may affect human behaviour. There are many types of smell. Studies show that there are seven main smells. These main types of smell are scent of flower, scent of mint, smell of ether, smell of decayed, smell of sweat, smell of camphor and musk (n.d. 2017).

According to Semin, our sweat is an important means of communication. Biochemistry of sweat provides information to others and it has the same effect on the person who get the smell. For example, when someone sweat because of fear, everbody who get the smell begin to fear though at different levels. This is the same for the sense of disgust. Studies show that smell is also a means of communication like other senses. Our first sense and communication is by means of smell. For instance, a baby can find its mother's breast by way of smell. The smell of rosemary arouse a feeling of a faster passing of time (Semin-Arman, 2013). The feelings someone has when he sweats, the same feelings are reflected on his environment. Smell of sweat under stress has a negative effect and smell of sweat in a good mood has a positive affect on people in the environment (Semin, 2015).

Not only the substance smelt and identified but also the intensity of the substance give rise to different feelings. For example, according to Hertz's experiment butyric acid molecule may be present in more than one and different substances' natural smell formula. It is a smell sensed in body odour, butter which is about to expire, parmesan cheese and puke. The smell which is a bad and keen sense of smell turns into a sweet and aethereal in a short time. It is a substance diluted and consciously put into perfumes which give the feeling that they include milk. People cannot identify the smells they are not familiar to and they cannot make sense of the smell if it is not look like any smell they recognize. In other words, people may ignore the smells they cannot express by words. In this case, is it possible to talk about the effects of positive and negative expectations, worries etc. on the description of sense of smell? People get used to the smell of their own living space and they develop behavioural patterns accordingly. Human brain has a fact like evaluating sense of smell in its own context. When someone get the smell of cheese and see it, he desires to eat it for instance. But when he get the same smell coming from a chest and a coffin in dark, it can be thought as the smell of a rotting corpse. Tomato and garlic can make someone hungry but they are never thought to be as candle smell in the living room (Ozan, 2014, s, 25-40). In other words, when we smell something intensively it can be disturbing but if we get the same smell for a little, it can arouse good feelings. What is more interesting is that we associate some smells with places. We may find a smell as appetizing in kitchen but we may find the same smell as disgusting in bedroom. The smell of living space may affect attitudes and feelings. 
It is not true to restrict smell to only body odour or perfumes. Shower gels, soaps and washing agents we used to wash our clothes make our body odour smelt difficult at a certain distance. Even if we do not use these things, there is industrial smell in the environment. It is hard to get the smell of opposite sex and it is no more a positive reference to choose a spouse. But it is still a negative reference to this choice. That is to say, one can refrain from someone if his smell does not appeal to him (Ozan, 2016, s. 96-97). We may explain this situation with the term "sexual compatibility" in everyday life.

As female body has a characteristic of fertility, they ara more vulnerable to sense of smell than males at certain periods. The time women are most vulnerable to sense of smell is when they are fertile. There is not a big difference between men and women's threshold of smell in other times. When in their periods, women's sense of smell is even lower than men's because the do not need sense of smell. Smell is an important means of breeding, choice of a spouse and knowing him/her (Ozan, 2016, s.97).

\section{Smell and Cultural Communication Differences}

Smell has an important place in cultural communication because we recognize smells by their social environment and we condition ourselves accordingly (Ozan,2016, s. 269). In 1930s, George Orwell based class distinction on "the smell of lower classes". The smell of working class is the reason for not only production relations and tools' ownership but also the major reason for unnegotiable controversy among classes. Physical feelings are distinguished and remarkable cause of liking and abhorance. According to Orwell, one may overcome racial-religious hatred, educational differences and the differences in ethics code but on emay not overcome physical urge (Ozan, 2016, s. 81). When compared with the upper class the reason for the smell of working class is that they have to work by their bodies and they do not have a bathroom in their houses. Proletarians do not hire a bath because of the high prices. As a result, cleaning has become something the rich have and so malodour has become a discrimination between the rich and the poor. Working classes do not have any restroom, kitchen and large bedrooms and they live in small and crowded houses. And this causes different smells to blend. The rich abstain from malodour. The smell of one's own and the environment gives clues about the position of their classes (Ozan, 2016, s. 82-83). In the ancient Roman and Greek civilizations people are classified among their bodily fluids (Özer, 2017, s. 137).

Sweat is a cooling system that body produces against overheating. So people living in a warm country are tend to sweat and smell more. In this case, secretion of the same smell molecules cannot be expected from an Alaskan and an Indian (Ozan, 2016, s.270).

The people consuming mutton emit a different and distinct smell to the others who do not consume. Besides nutrition, different ethnic groups smell differently according to genes, the amount of body hairs or structure of the glands. The main sweat gland "ecrine gland" is one of the olfactive character sources that turns what we eat into sweat. Occurence of smell, its source and structure of the genes that drive smell out of the body are important factors. Along with it, the country's cultural structureof bazaar and the products sold there independent of hygiene are the determiners about the ethnic smell. For example, even when a French has a shower and wear clean clothes, he may smell different in comparsion to an American. Because in French detergent industry some chemicals useful for removing the oil acids caused by sweating are not used fort he reason that they do not decompose in nature or it takes a long time. Canadians who are accustomed to their clean and odour-free country may sense the deep and intense smell of a perfume as bad (Ozan, 2016,s. 74-80). 
Because products with lemon smell are assumed as cleaner, it is used generally in cleaning products. Lemon is in citrus fruits family and it belongs to the same family with bitter orange blossom which is also called as"neroli". But neroli is thought to be romantic and even sexy. If industry were to find out neroli at first and use it in cleaning, a perception of cleaning would be consist. Because neroli and lemon belong to the same family, their smell is related with each other and associated with cleaning and hygiene. The usage of fruits, plants and their place of use and frequency of usage is a situation that affects social and cultural associations. We can give the usage of cologne in Turkish culture as an example for this situation. In Turkish culture cologne is offered after the use of toilet or before the bus ride. As these smells is used like that in Turkish culture, they do not evoke romantic associations but evoke hygenic associations (Ozan, 2016, s. 271-272).

Smell is so much important in cultures that it is estimated that Americans spent more than 3 million dollars for deodorants in 1998. The amount of this money is too much just for smelling good. While the natural smell of the body is preferred in other cultures, Americans' preference is explained by Winter like that; " We cannot have a bad breath, sweaty armpits and a distinct genital odour in society. You may tell the others that you need to make your hair cut or wash your face but if you tell them that they smell bad, this is really embarrassing." Our olfaction affects how we realize others and how we communicate (Richmond, McCroskey, Hickson, 2008, s. S. 170).

\section{How Can We Use Smell to Increase Consumption in Service and Consumption Sectors?}

Consumption is a general meaning given to the activities and costs in order to meet a need. Maslow observes the needs in five stages;

1. Physiological needs: Breeding, shelter and food etc.

2. Safety needs: Protection against dangers

3. Love and belonging needs: Love and friendship etc.

4. Esteem needs: Fame, self-respect and reputation etc.

5. The needs for self actualisation: creativity etc. (Odabaşı, 2013, s. 22)

In this case charateristics of olfaction and usage of smell meet many needs like breeding, food and water, shelter, bonding and gaining a statue. Individuals convey something about themselves by way of using products and services. As products and brands are signs and symbols, causes of nominal consumption can be as below;

1. To determine the social class or statue

2. To identify oneself and to take on a role

3. To create a social being and to protect it

4. To express oneself to himself/herself and to others

5. To reflect one's identity

(Odabaşı, 2013, s.85). Smell is used as a means of class expression in order to express oneself and communicate with oneself and the others. Perfume and aromatic products are important parts of consumption culture providing all these.

Scent marketing strategy is a marketing strategy used effectively by brands. Ranked first among the human senses olfaction attracts the attention of brands. One can live without seeing or hearing but one cannot live without breathing. By taking into account that a person breaths 20 thousand times and smell the environment, brands try to affect the customers' decision of buying with scent pazarlama. Conducted studies show that according to the smell of the environment customers' impressions get positive or negative. When a customer gets a good impression, his/her duration of stay at a store or place increases by $20 \%$ and this increases the chance of selling by $70 \%$. Senses are 
not only effective in retail consumption but also in every decision of buying. And the parts affected in brain are indicated by scientific technics. Stimulants should be involved in so as to repeat the decision of buying and keeping it (Gökyer, 2015).

Advertising perfume is one of the most difficult jobs because there are so few and limited words to describe the smell. This is called "olfactory verbal gap". Besides this, perfume is a symbol of statue and its inexpensiveness is not a criteria but it is something to avoid. Perfume usage is not only means smelling nice. And also the smell should give a message about who we want to be in the social environment because smell has been a symbol of statue by advertisements. As a result of this, the life symbols that one has or want to have are put forward with the visual or text-based messages. It is centered on the dreams and fantasy which arouse or expected to arouse by avoding the information about the product in advertisements (Ozan, 2015, s. 209-210).

\section{Conclusion}

Smell is a significant factor that affects our liking, hatred, bias against every person and every object, starting and lasting form of our communication even when we feel impassive.

Smell obviously means influencing others and communicate with them. Although smell is an invisible element of non-verbal communication, it is very powerful. First of all, smell may be used for increasing the perception of attraction between two people. At the same time, smell is also an element of attraction about foods. Thirdly, smell provides us to remember our memories about the environment, people and objects in the past. Fourthly, adaptation of smell makes us accomodate ourselves to an environment. For example, when we go into a chocolate store, we immediately get the aromatic smell of chocolate. Fifthly, our experiences which we will call smell memory make us give a spontaneous reaction to something happened. Smell is used in the education of deaf mute. And also smell is connected to some diseases and gives information about these diseases. Yellow fever smells like butcher. Scurvy and smallpox smell like rotten. Typhoid fever smells like freshly-baked bread. Diphtheria smells sweet and typhoid smells like an apple. Today many of these diseases are not present in America but many diseases like alcoholism and diabetic coma can be realized thanks to the power of smell. In conclusion, environmental factors play an important role in communication. These factors influence our reactions with others, our emotional status and perceptions. When we make out such environmental factors, we may understand communication better (Richmond, McCroskey, Hickson, 2008, s. S. 175-176).

Avoiding keen and strong odours on us and in the environment we communicate if it is possible and the environment belongs to us may hinder a bias in the communication process. Scents used in stores may be chosen as relaxing and pleasing so as not to disturb customers. So customers may shop with pleasure. Or else, they may want to leave there immediately. Hygienic feeling smells can be suggestive of reliable and relaxing impressions on people in health sector and clinics. It is essential that our perfumes should express our characters rather than being strong or light. For this reason making our choices accordingly and not to choose a smell simply because its fashionable may shape our attitudes and the attitudes towards us. On the other hand, our particular smell is a way of non-verbal communication that holds our thoughts and feelings and communicates with others even when we think not to. Our unbiased and positive approach may shape our bodies, body odour and naturally our ways of communication.

\section{Bibliography}

Devito, Joseph A. Interpersonal Messages Communication and Relationship Skills. USA: Pearson, 2008. 
Goldstein, Bruce. Sensation \& Perception. Seventh Edition. China: Wadsworth Cengage Learning, 2007.

Gökyer, Eren. 2015, https://erengokyer.com.tr/2015/06/09/pazarlamanin-gizli-gucukoku-2/

Landback, Patrick. https://lucian.uchicago.edu/blogs/mediatheory/keywords/olfaction/2007

Odabaşı, Yavuz. Tüketim Kültürü Yetinen Toplumdan Tüketen Topluma. İstanbul: Sistem, 2013.

Ozan, Vedat. Kokular Kitabı. 3. Baskı. İstanbul: Everest, 2016.

Ozan, Vedat. Kokular Kitabı-II Parfümler. İstanbul: Everest, 2015.

Özer, Gülcan. İnsan Halleri. İstanbul: Sözcü, 2017.

Polat, Emrah. http://www.milliyet.com.tr/kokunun-davranislara-etkisi-nedir-pembenardetay-ruhsagligi-1998600/

Richmond, Virgınıa Peck., McCroskey, James C., Hickson, Mark L. Nonverbal Behavior in Interpersonal Relations. Sixth Edition. USA : Pearson, 2008.

Sezgin, Oğuz. http://www.gercekbilim.com/insanlar-kokularla-kemosinyaller-yayarakiletisim-kurabiliyor/06 Kasım 2012

Şemin, Gün Refik-Arman, http://www.hurriyet.com.tr/korkunun-kokusu-var-ve-o-kokubulasiyooor-23285486, 15. Mayıs 2013.

Şemin, Gün Refik. http://www.hurriyet.com.tr/ter-kokusu-mutluluk-verebilir-29059226. 21. Mayıs 2015

Şemin, Gün. http://www.saglikekibi.com/can/pratikbilgi/prof-dr-gun-semin-pisirikerkegi-kokusu-ele-veriyor.html. 21.02.17.

n.d. http://www.bilgiustam.com/burnun-yapisi-ve-koku-almanin-canlilar-icin-onemi/ 2017

n.d. http://www.evrimagaci.org/makale/185. 2017. (2)

n.d. https://www.medikalakademi.com.tr/koku-alamama-kaybi-anosmi-nedir-nedenlerive-tedavisi/2015

nd. Nasonov feromonları,https://tr.wikipedia.org/wiki/Feromon. 2017 (3) 